\title{
The essential NHS
}

\author{
Fiona Godlee editor in chief, The BMJ
}

With only a week now until the UK general election, you won't be surprised to find many articles on the NHS recently on thebmj.com. For readers outside the UK there's lots of coverage of other issues too, though to many around the world as well as in the UK the NHS represents more than just healthcare: it stands as a globally unique and effective intervention for social justice. As Alan Maynard says (doi:10.1136/bmj.h2254), if he ruled the NHS he would find every way to demonstrate the remarkably good value that the UK's citizens get from their NHS.

"Protection of this modest spending, ensuring that people don't have to pay out of their own pockets in times of ill health and enshrining the principle of collective responsibility for each other's healthcare, remains essential."

Others go further, with calls not only to protect current spending but to increase it. This is the bottom line of our letter to the new secretary of state for health, whoever he or she may be (doi:10. 1136/bmj.h2296). And it is also Jan Filochowski's solution to the continuing crisis in the NHS (doi:10.1136/bmj.h2122). We cannot, he says, continue to respond to financial challenges by cutting costs. This merely reduces capacity. The NHS has coped with this progressive squeeze not by reducing demand, which requires a whole range of other societal measures, but by displacing it: emergency care patients occupying elective beds, patients needing social care occupying emergency beds, and so on across the system. The result is that care is less safe and costs more. This false economy could be replaced, Filochowski says, by creating enough capacity to enable patients to pass through every potential bottleneck without delay. "The solutions are there if we want them, and cheaper than what we are doing now."
It would be good if the politicians were listening. Although the NHS is a major pre-election issue-just look at the wild and whimsical promises pouring in from all sides, says Margaret McCartney (doi:10.1136/bmj.h2269)—health is unlikely to top anyone's list of priorities when the parties sit down to negotiate coalition deals. This was the conclusion of our roundtable discussion after last week's health hustings (doi:10.1136/bmj. $\mathrm{h} 2248$ ). Our panellists agreed that there was a need for new money and new thinking and for the next health secretary to adopt a new, less interventionist role. But they were sceptical about claims that the Health and Social Care Act could be repealed without another major reorganisation or that repealing the act would reverse the marketisation of England's NHS.

If she had been on the panel Allyson Pollock would have had a great deal to say. She and Peter Roderick make a plea for the act to be repealed and replaced with a new NHS Bill (doi:10. 1136/bmj.h2257). This, they say, is necessary to protect the NHS from being broken up and privatised. Meanwhile, new international trade agreements such as the Transatlantic Trade and Investment Partnership (TTIP) currently being negotiated will make further marketisation in healthcare more likely, say Lucy Reynolds and Martin McKee, and secrecy will mean that we don't know that it's happening. Amid the confusion of the election campaign, this at least seems clear: health should be excluded from TTIP.

Cite this as: BMJ 2015;350:h2303

๑ BMJ Publishing Group Ltd 2015 